\title{
Assessment of Pollution Status of a Coastal Lake System using Satellite Imagery
}

Sheela $\mathrm{AM}^{1 *}$, Letha $\mathrm{J}^{2}$, Sabu Joseph ${ }^{3}$, Ramachandran $\mathrm{KK}^{4}$ and Justus $\mathrm{J}^{5}$

${ }^{1}$ Directorate of Environment and Climate Change, Thiruvananthapuram, Kerala, India

${ }^{2}$ Director of Technical Education, Thiruvananthapuram, Kerala, India

${ }^{3}$ Department of Environmental Sciences, University of Kerala, Kariavattom P. O., Thiruvananthapuram, Kerala, India

${ }^{4}$ Centre for Earth Sciences, Akkulam, Thiruvananthapuram, Kerala, India

${ }^{5}$ St.Xavier's College, Thumba, Thiruvananthapuram, Kerala, India

\begin{abstract}
Water pollution is a major threat to the existence of living beings. The restoration measures can be taken by assessing the extent of pollution in water bodies using various water quality indices. National Sanitation Federation Water Quality Index (NSFWQI) is the most widely used index. Usually NSFWQI is determined by collecting and analyzing water samples from various locations and it is a tedious and expensive process. Trophic status is usually ascertained from satellite imagery of Landsat TM. Here attempt has been made to quickly assess the pollution status in a vast area (Akkulam-Veli Lake, Kerala, India) directly from the satellite imagery (IRS P6- LISSIII) using NSFWQI. It is also attempted to calculate the $\mathrm{pH}$, dissolved oxygen (DO), biochemical oxygen demand (BOD) and fecal coliforms $(\mathrm{FC})$ in the Lake system.
\end{abstract}

Regression equations for the prediction of NSFWQI, $\mathrm{pH}, \mathrm{DO}, \mathrm{BOD}$ and FC from radiance values from green, red, NIR and SWIR bands of satellite imagery were developed. The study reveals that the simple regression equation formed by the ratio of radiance in the green and the red bands, which yields a strong correlation coefficient for the prediction of NSFWQI. For the prediction of DO, the best equation is the simple regression equation formed by the ratio of radiance in green and red bands with a strong correlation. For BOD, multiple regression equation was formed by the radiance in the red and SWIR bands with a strong correlation. The best equation for predicting $\mathrm{pH}$ is the regression equation with the ratio of green and red bands with a strong correlation. But for fecal coliform, multiple regression equation is the best equation formed by the ratio of radiance in the green and SWIR bands with a low correlation coefficient. The performance of this model can be improved by using a large set of data.

The spatial variation of these utmost important water quality characteristics is derived from imagery using remote sensing techniques. It is also found out whether the water quality is conforming to the standards or not for envisaging control measures. IRS P6-LISSIII imagery can give a quick assessment of the pollution status of the Lake system using water quality index (NSFWQI). Control measures can accordingly be adopted on priority basis. Satellite imagery can be used for the quick assessment of urban pollution status of water bodies all over the world.

Keywords: IRS P6; Satellite imagery; Remote sensing; Pollution status; Water quality index; Akkulam-Veli Lake

\section{Introduction}

Water pollution is mainly due to growing population which is responsible for rapid urbanization, industrialization, and agricultural development all over the world. These activities increase the disposal of wastes in to water bodies and aggravate pollution problems. These result in many dreadful diseases like typhoid, cholera, jaundice etc. Vector borne diseases like malaria, dengue fever, filariasis, chikungunya etc., are also the result of water pollution. The need of the hour is to restore the water quality and this can be achieved only by the identification of extent of pollution in water bodies.

Usually water samples are collected from various locations and are analyzed in a laboratory for getting information on the concentration of water quality parameters, which is a tedious process. Instead of the above process, the concentration of water quality parameters can be assessed directly from satellite imagery over a vast area and is less expensive.

Remote sensing basis (radiative transfer) for water pollution are widely reported in literature and are based on concepts as Inherent and Apparent Optical Properties of the Water, water coefficients of absorption and of scatting, water leaving radiance, surface reflectance, under-water reflectance $[1,2]$. Satellite images have been widely used to monitor the water quality [3-10]. Satellite and aircraft remote sensing systems, were used in the assessment of water quality parameters, such as temperature, chlorophyll-a, turbidity, total suspended solids, and secchi disk depth for Lakes and reservoirs [11-13]. Wang et al. and Houma et al. $[14,15]$ developed models for the prediction of organic parameters using satellite imagery. Vincent et al. (2005) [16], developed Landsat TM algorithms for mapping the content of total coliform bacteria and e-coli in the surface water. Virgilo et al., developed a model that predicts the water quality index of surface water in Medrano Creek, Argentina.

Some of the prominent Indian contributions include the work of Tripathy and Singh, who developed a model for obtaining concentration of chlorophyll-a using IRS-1C data. Samson et al. [17] assessed the

*Corresponding author: Sheela AM, Directorate of Environment and Climate Change, Thiruvananthapuram, Kerala, India, Tel: 9446373462, E-mail: Sheelaamoses@gmail.com

Received May 11, 2013; Accepted July 02, 2013; Published July 15, 2013

Citation: Sheela AM, Letha J, Joseph S, Ramachandran KK, Justus J (2013) Assessment of Pollution Status of a Coastal Lake System using Satellite Imagery J Geophys Remote Sensing 2: 110. doi:10.4172/2169-0049.1000110

Copyright: (c) 2013 Sheela AM, et al. This is an open-access article distributed under the terms of the Creative Commons Attribution License, which permits unrestricted use, distribution, and reproduction in any medium, provided the original author and source are credited. 
water quality of Harike wetland in India using satellite imagery from the Indian Remote Sensing satellite (IRS P6).

There are numerous water quality indices namely National Sanitation Foundation Water Quality Index (NSFWQI), Oregon Water Quality Index(OWQI), Canadian Council of Ministers of the Environment Water Quality Index (CCME WQI) in use today. In NSFWQI, the selection parameters are based on Delphi method and the models were formulated in additive and multiplicative forms [1]. OWQI is the refined form of NSFWQI. CCMEWQI compares observation to a bench mark instead of normalizing observed values to subjective rating curves, where bench mark may a water quality standard or site specific background concentration. The main advantage of NSFWQI is that critical parameters namely $\mathrm{pH}$, dissolved oxygen (DO), biochemical oxygen demand (BOD) and fecal coliform (FC) are used in the study. In water bodies, BOD is an indicator of organic matter; fecal coliform is an indicator of sewage pollution; $\mathrm{pH}$ represents ionic composition of water and dissolved oxygen represents health of water. The standards for these significant water quality parameters are usually prescribed.

Samantray et al. [18] assessed the water quality index in Mahanadi and Atharabanki rivers and Taldanda canal in Paradip area using NSFWQI. The findings highlighted the deterioration of water quality in the rivers due to industrialization and human activities. Sheela et al. [19] assessed the environmental status of the Akkulam-Veli Lake using NSFWQI for all the three seasons. The study revealed that the water quality of the Akkulam-Veli Lake is 'bad' during premonsoon. The water quality is 'bad' in the Akkulam Lake and is 'medium' in the Veli Lake during monsoon and post monsoon. Sheela et al. [20] revealed that the AV Lake is in hyper eutrophic condition.

The satellite imagery usually used was Landsat TM imagery. The relative low cost, easy availability, temporal coverage and spatial resolution of Indian Remote Sensing (IRS P6-LISS3) satellite imagery led to its use for prediction.

A small amount of impurities can cause significant changes in the refractive index of a substance. Substance containing more polarizer groups (aromatic rings) will normally has higher refractive index than substance containing less polarizer groups. (http://www2.ups. edu/faculty/hanson/labtechniques/refractometry/interpret.htm). The pollutants change the refractive index in water and which in turn changes the reflectance of NIR and SWIR in water.

The satellite imagery usually used was Landsat TM imagery. The relative low cost, easy availability, temporal coverage and spatial resolution of Indian Remote Sensing (IRS P6-LISS3) satellite imagery led to its use for prediction. Trophic state index using secchi disc depth which determines the eutrophication status of the Lake system has been ascertained successfully using IRS P6 LISS III imagery. The Lake characteristics namely depth, temperature and turbidity have been measured successfully using IRS P6 LISS imagery. The prediction of sodium and chloride content in the Lake water was also done from the IRS Imagery.

Usually chlorophyll, temperature, suspended solids and secchi disk depths are only ascertained using satellite imagery. As pollution of our water bodies is one of the major problems faced by mankind, no serious attempts have been made for the assessment of pollution status of the Lake using water quality index from multispectral imagery of IRS satellite. NSWQI is an ideal indicator of pollution as the same is derived from ideal water quality parameters namely $\mathrm{pH}$, dissolved oxygen, biochemical oxygen demand and fecal coliform organisms. Ionic substances, dissolved oxygen, and fecal coliform bacteria present in water have specific spectral characteristic. Hence, in this study, an attempt has been made for the estimation of NSFWQI using IRS P6LISS III imagery. Here attempt is also made to assess $\mathrm{pH}, \mathrm{DO}, \mathrm{BOD}$ and FC in the Lake water and to confirm whether water quality is confirming to the standards or not so that control measures can be adopted in the affected area in a fast manner.

\section{The study area}

The Akkulam-Veli Lake (AV Lake) is located at the north-western part of Thiruvananthapuram along the SW coast of India (Figure 1). The AV Lake has an area of about $0.76 \mathrm{~km}^{2}$, and is situated between $8^{\circ} 31^{\prime} 14^{\prime \prime}$ and $8^{\circ} 31^{\prime} 52^{\prime \prime}$ north latitudes, and $76^{\circ} 53^{\prime} 12^{\prime \prime}$ and $76^{\circ} 54^{\prime} 6^{\prime \prime}$ east longitudes. It is a shore perpendicular linear Lake with the seaward part abutting against the shoreline; and it is separated from the shore by a sandbar during non-rainy season. The Lake is partially divided into two by the existence of a bund across its length (bridge of NH Bypass). The western part towards the sea, with a length of $1.25 \mathrm{~km}$ and a width of around $100 \mathrm{~m}$, forms the Veli Lake. The eastern part starting from the bund forms the Akkulam Lake. The silting in the Akkulam Lake affected the free flow of water from the Akkulam Lake to the Veli Lake. For most part of the year, the Veli Lake remains separated from the sea by a sandbar of approximately $150 \mathrm{~m}$ in length and $20-40 \mathrm{~m}$ in width. The Lake mouth remains open usually for 10 to 14 days, depending upon the influx of land drainage to the Lake. This episode repeats six to eight times a year [21].

The streams and canals that drain through the Akkulam-Veli Lake basin include the Kannamoola stream, T. S. Canal (Parvathy Puthan Ar), and the Kulathur stream. The Akkulam and Veli boat clubs on its banks are the major tourist attraction. The AV coastal zone enjoys a

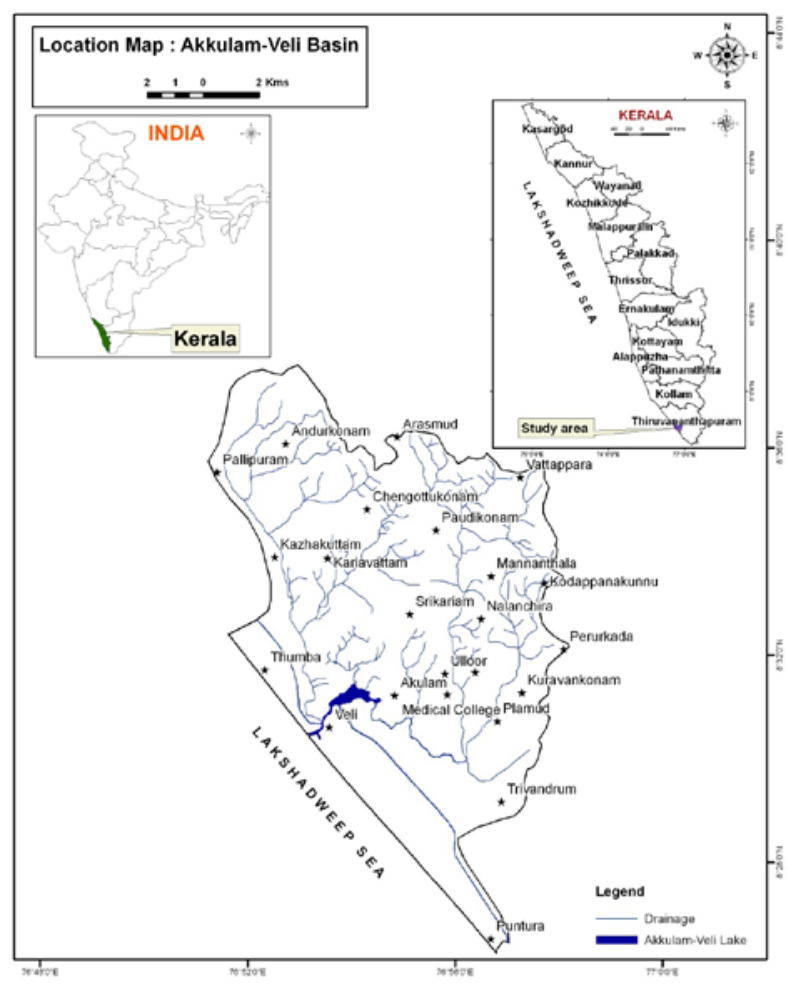

Figure 1: Location Map of the Akkulam-Veli Lake Basin (Sheela et al., 2010). 
Citation: Sheela AM, Letha J, Joseph S, Ramachandran KK, Justus J (2013) Assessment of Pollution Status of a Coastal Lake System using Satellite Imagery. J Geophys Remote Sensing 2: 110. doi:10.4172/2169-0049.1000110

Page 3 of 11

humid tropical climate with an average annual rainfall of $1823.7 \mathrm{~mm}$, relative humidity of $76.2 \%$, and a temperature of $27.50^{\circ} \mathrm{C}$ during 2008 .

\section{Material and Methods}

\section{Sampling scheme}

A total of eleven sampling stations (1-11) are identified for the AV Lake covering both Akkulam with seven stations numbering from 1 to $7(n=7)$ and Veli with 4 stations numbering from 8 to $11(n=4)$. The station 1 is located in the upstream portion of the Akkulam Lake where the Kannamoola stream joins it. The stations with numbers 2, 3, 4 and 6 are located mainly in the flow path of the Lake (Figure 2). However, stations 5 and 7 are located away from the flow path on the northern side of the Akkulam Lake. Station number 8 is located in the upstream part of the Veli Lake, and it is the confluence point of the Parvathi Puttan Ar. The other stations namely, 9, 10, and 11 are located in the flow path of the Veli Lake towards the seaside. Water samples were collected monthly from the above stations from December 2007 to March 2009, on the same date and time at which IRS P6 over passed the study area. The geographic locations of the sampling points are recorded using GPS. The parameters analysed include dissolved oxygen (DO), biochemical oxygen demand (BOD), $\mathrm{pH}$, and fecal coliforms (FC). The Winkler's method was followed for the analysis of DO and BOD. Membrane filter technique was used to determine FC. Analysis was done as per the standard procedures (APHA, 2005) [22].

\section{Calculation of National Sanitation Foundation Water Quality Index (NSFWQI)}

National Sanitation Foundation Water Quality Index (NSFWQI) has been the most commonly used index of the different water quality indices (Ott, 1978) [23]. It was developed to provide standardized method for comparing the water quality of water bodies.

(www.bcn.boulder.co.us/basin/watershed/wqi_nsf).

$\mathrm{p}$

NSFWQI $=\sum \mathrm{w}_{\mathrm{i}} \mathrm{I}_{\mathrm{i}}$

$\mathrm{i}=1$

Wherein $I_{i}$ is the sub- index for the $\mathrm{i}^{\text {th }}$ water quality parameter

$\mathrm{w}_{\mathrm{i}}$ is the weight associated with the $\mathrm{i}^{\text {th }}$ water quality parameter

$\mathrm{p}$ is the number of water quality parameters

NSFWQI has been modified for applying them on the Indian

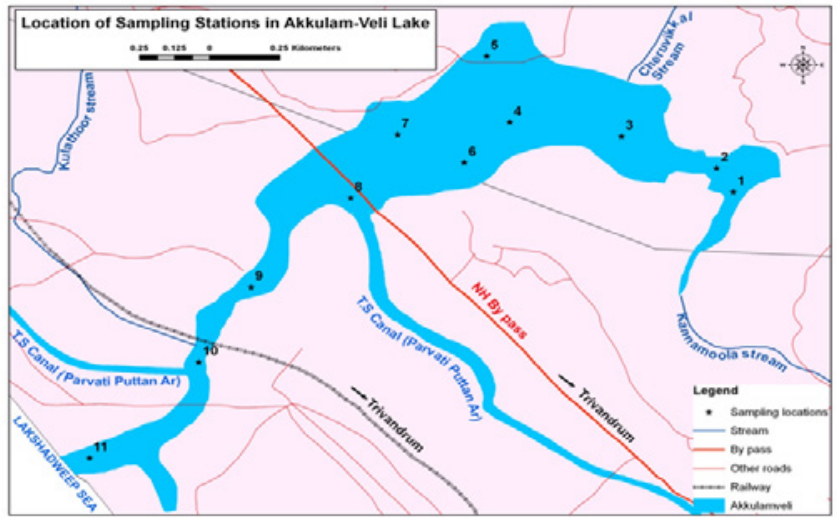

Figure 2: Location of Sampling Stations in the Akkulam-Veli Lake (Sheela et al. 2010).

\begin{tabular}{|c|c|c|}
\hline Water Quality Parameter & Range Applicable & Equation* \\
\hline \multirow[t]{3}{*}{ Percent Saturation DO } & $0-40 \%$ & $\begin{array}{l}I_{D O}=0.18+0.66^{*} \\
(\% \text { saturation } D O)\end{array}$ \\
\hline & $40^{+}-100 \%$ & $\begin{array}{l}I_{D O}=-13.5+1.17^{*} \\
(\% \text { saturation } D O)\end{array}$ \\
\hline & $100^{+}-140 \%$ & $\begin{array}{l}I_{D O}=163.34-0.62^{*} \\
(\% \text { saturation } D O)\end{array}$ \\
\hline \multirow[t]{2}{*}{$\mathrm{BOD}$ in $\mathrm{mg} / \mathrm{l}$} & $0-10$ & $I_{B O D}=96.67-7^{*} \mathrm{BOD}$ \\
\hline & $10^{+}-30$ & $I_{B O D}=38.9-1.23^{*} \mathrm{BOD}$ \\
\hline \multirow[t]{4}{*}{$\mathrm{pH}$} & $2-5$ & $I_{p H}=16.1+7.35^{\star} \mathrm{pH}$ \\
\hline & $5^{+}-7.3$ & $I_{p H}=-142.67+33.5^{*} \mathrm{pH}$ \\
\hline & $7.3^{+}-10$ & $I_{p H}=316.96-29.85^{*} \mathrm{pH}$ \\
\hline & $10^{+}-12$ & $I_{p H}=96.17-8^{*} \mathrm{pH}$ \\
\hline \multirow[t]{3}{*}{$\mathrm{FC}(\mathrm{no} . / 100 \mathrm{ml})$} & $1-10^{3}$ & $I_{\text {Coli }}=97.2-26.8^{*} \log (\mathrm{FC})$ \\
\hline & $10^{3+}-10^{5}$ & $I_{\text {Coli }}=42.33-7.75^{*} \log (\mathrm{FC})$ \\
\hline & $10^{5+}$ & $I_{\text {Coli }}=2$ \\
\hline
\end{tabular}

${ }^{*}$ CPCB (1986)

Table 1: Sub-index Equations for National Sanitation Foundation Water Quality Index (NSFWQI).

\begin{tabular}{|c|c|c|}
\hline NSFWQI & Descriptor words & Category \\
\hline $0-25$ & Very bad & A \\
\hline $26-50$ & Bad & B \\
\hline $51-70$ & Medium & C \\
\hline $71-90$ & Good & D \\
\hline $91-100$ & Excellent & E \\
\hline
\end{tabular}

Table 2: Descriptor Words suggested for NSFWQI.

\begin{tabular}{|c|c|c|c|c|c|}
\hline No. & \multicolumn{2}{|c|}{ Characteristics } & \multicolumn{2}{|l|}{ Unit } & Value \\
\hline 1. & \multicolumn{2}{|l|}{ Resolution } & \multicolumn{2}{|l|}{$\mathrm{m}$} & 23 \\
\hline 2. & \multicolumn{2}{|l|}{ Swath width } & \multicolumn{2}{|l|}{$\mathrm{km}$} & 141 \\
\hline 3. & \multicolumn{2}{|l|}{ Repetition } & \multicolumn{2}{|l|}{ days } & 24 \\
\hline 4. & \multicolumn{2}{|l|}{ Data range } & \multicolumn{2}{|l|}{ bit } & 7 \\
\hline \multicolumn{6}{|c|}{ Band Details } \\
\hline Band & Wave length & $L_{\min }$ & $L_{\max }$ & $\mathbf{D}_{\max }$ & $\mathrm{L}_{\max } / \mathrm{D}_{\max }$ \\
\hline 2 (green) & $0.52-0.59$ & 0 & 12.06400 & 255 & 0.0473098 \\
\hline 3 (red) & $0.62-0.68$ & 0 & 15.13100 & 255 & 0.059337 \\
\hline 4 (NIR) & $0.77-0.86$ & 0 & 15.75700 & 255 & 0.061792156 \\
\hline 5 (MIR) & $1.55-1.7$ & 0 & 3.39700 & 255 & 0.0133216 \\
\hline
\end{tabular}

Table 3: Characteristics of IRS-P6.

conditions [24]. The parameters namely dissolved oxygen (DO), biochemical oxygen demand (BOD), $\mathrm{pH}$, and fecal coliforms (FC) are considered as important water quality parameters for classification in India. The modified weights $\left(\mathrm{w}_{\mathrm{i}}\right)$ for $\mathrm{DO}, \mathrm{BOD}, \mathrm{pH}$, and $\mathrm{FC}$ are 0.31 , $0.19,0.22$, and 0.28 respectively. The equations for determining subindex of these water quality parameters are given in Table 1 . Table 2 gives the descriptor words suggested for reporting NSFWQI [23]. The values of NSWQI on 12-12-2007 and 16-2-2009 are determined from DO, BOD, pH, and FC of water samples collected using Eq.1 and the equations in Table 1.

\section{Processing of satellite imagery}

The selection cloud free imagery of IRS P6-LISS III, has been done using the browsing facility in NRSC. The characteristics of IRS P6-LISS III imagery is given in Table 3. Though water samples were collected monthly on the date of over pass of satellite imagery, cloud free imagery was obtained only for the dates 12-12-2007 and 16-2-2009. Water samples were taken from eleven sampling stations from the AV Lake. Due to the interference of aquatic vegetation, the water-quality data of eight sampling stations (Stations 2, 5,6,7,8,9,10, and 11) have only been 
used for the development of regression equations. The satellite imagery data on 12-12-2007 is used for this purpose. The regression equation developed is applied onto the satellite imagery of another date, 16-22009 for validating the results. The data from the sampling stations namely, $4,5,6,7,8,9,10$, and 11 can only be used for the validation purpose. ERDAS-Imagine 9.1 software is used for the image processing of the satellite imagery. Satellite imagery is georeferenced into WGS 84 coordinates, and resampled using the nearest neighbor. The water spread area of the AV Lake, is created using ERDAS [21]. The raw digital numbers of the imagery is converted into radiance using ERDAS Imagine 9.1. The similarity between the satellite images in two dates is assessed by comparing bias in the two images.

\section{Development of regression models}

The Statistical Package of Social Sciences (SPSS) software is used for developing regression model. Regression models are developed between the parameters, namely the radiance values obtained from the analysis of satellite imagery data as stated above (imagery corresponding to 12-12-2007) and NSFWQI, DO, BOD, pH, and FC in the Lake water. Radiance from the green, red, near infrared, and medium infrared bands, are used as independent variables and the NSFWQI, DO, BOD, $\mathrm{pH}$, and $\mathrm{FC}$ are used as the dependent variable. Multiple regression equations are developed by taking into consideration multicollinearity [21].

Simple regression equations are formulated by using either the radiance in individual bands or spectral ratio from the imagery of 1212-2007 as independent variable and the NSFWQI, DO, BOD, pH, and $\mathrm{FC}$ as dependent variable. The values of these dependent variable are obtained as explained in section 3.1. First, the independent variables one by one are correlated with the values of NSFWQI, DO, BOD, $\mathrm{pH}$, and FC. The strongly correlated independent variable either the radiance in individual band or spectral ratio is used for the development of predictive models. As mentioned earlier, we get five sets of these equations since there are five sets of dependent variables, i.e. five sets of estimated values of NSFWQI, DO, BOD, $\mathrm{pH}$, and FC.

Multiple regression equations are developed using more number of independent variables. The independent variables selected are radiance values obtained from satellite imagery data in different bands. The dependent variable is any one of NSFWQI, DO, BOD, pH, and FC. Herein also we get different forms of multiple regression equation for the five sets of estimated values of NSFWQI, DO, BOD, pH, and FC.

\section{Validation of predictive model}

The multiple regression equation and the simple regression equations, thus developed all conforming to 12-12-2007 are validated using the data for another date as explained below.

Using the radiance in the satellite imagery of a different date, i.e., 162-2009, values of NSFWQI, DO, BOD, pH, and FC are calculated using the regression equations developed. The values of NSFWQI, DO, BOD, $\mathrm{pH}$, and FC so obtained are compared with the values of NSFWQI, DO, $\mathrm{BOD}, \mathrm{pH}$, and $\mathrm{FC}$ estimated from field measured data on water quality parameters on the same date. Thus the predicted values are compared with the actual values. The best predictive model is the one that has strong correlation coefficient with the actual value of NSFWQI, DO, $\mathrm{BOD}, \mathrm{pH}$, and FC. Thus from the different sets of equations developed a particular equation is selected for predicting each parameter and these may be termed as the feasible set of regression equation.

\section{Preparation of maps from the satellite imagery}

The feasible set of regression equations thus developed for predicting NSFWQI, DO, BOD, $\mathrm{pH}$, and $\mathrm{FC}$ are now input into the module 'spatial modeler' in ERDAS Imagine 9.1. Simultaneously the satellite imagery corresponding to the dates 12-12-2007, and 16-2-2009 are also input into this module. The output obtained after simulation is the map showing the spatial variation of NSFWQI, DO, BOD, $\mathrm{pH}$, and FC for the entire Lake system on both the dates i.e. 12-12-2007, and 16-2-2009. Colour slicing technique is used for the preparation of map.

\section{Results and Discussion}

The imagery showing the radiance is obtained using ERDAS Imagine 9.1. Here an attempt has been made to test whether the imagery in these two different dates can be compared to verify whether the two imageries are in the same atmospheric condition. For that, two stations each in Air port, sea and shadow regions are identified for the comparison of bias in the two images. DN values of all the four bands in each location of the imagery on 12-12-2007 are extracted. DN values on the same location of the imagery on 16-2-2009 are also extracted. $\mathrm{DN}$ value of the green band (band2) of the imagery on 12-12-2007 is plotted against the corresponding values at the same pixel location in the SWIR band. The scatter diagram is plotted and a regression line is fitted for the data set (Figure 3). The X-intercept obtained is 62. The same procedure is repeated for the imagery on 16-2-2009. Here also the $\mathrm{X}$-intercept obtained is 62 (Figure 4). As the $\mathrm{X}$-intercept obtained

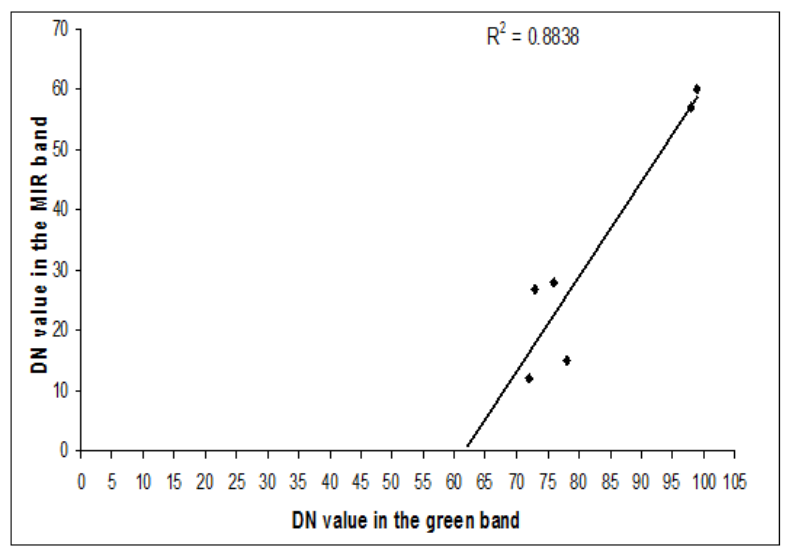

Figure 3: Scatter Plot of DN Values of the Green Band Vs. MIR Band of the Imagery on 12-12-2007.

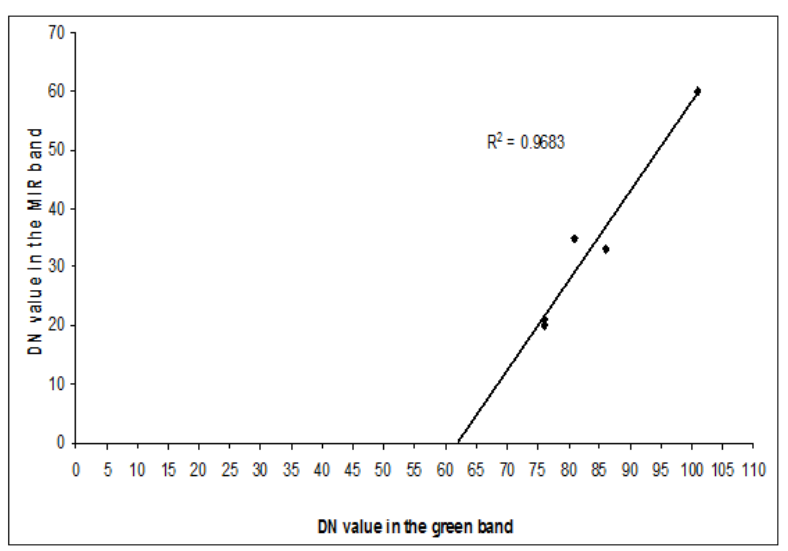

Figure 4: Scatter Plot of DN Values of the Green Band Vs. MIR Band of the Imagery on 16-2-2009. 
is same for the two images, it can be concluded that bias is same for the two images. The procedure is repeated with red band and NIR band with the SWIR band on both dates. The X-intercept obtained is 21 in the case of red band and 10 in the case of NIR band for both images. This confirms that bias is same for the two images. Hence it can be concluded that the imagery on 12-12-2007 can be compared with the imagery on 16-2-2009.

Further, the purpose of illumination correction is to remove shadowing effects from remote sensing images particularly in areas with steep terrain. The effects of topography coupled with a low sun angle at the time of satellite overpass, creates significant shadowing effects in remote sensing data. The study area lies in the tropical region between $8^{\circ} 31^{\prime} 14^{\prime \prime}$ and $8^{\circ} 3152^{\prime \prime} \mathrm{N}$ latitudes and $76^{\circ} 53^{\prime} 12^{\prime \prime}$ and $76^{\circ} 54^{\prime} 6^{\prime \prime} \mathrm{E}$ longitudes. High sun angle exists on both days on 12-12-2007 and 162-2009. As these two dates fall on the same season, there is not much difference in solar zenith. Albedo effect is also less in water in a high sun angle area. As the study area lies in a high sun angle and flat area, the effect of illumination is less. Hence the digital numbers of the imagery are converted into radiance using ERDAS Imagine 9.1 and are used for analysis.

Radiance values were used for the determination of trophic state index of the Lake system using IRSP6 LISS III imagery for the determination of temperature, depth and turbidity in a Lake system and for the determination of sodium and chloride content.

\section{Estimated values of NSFWQI}

The measured values of percent saturation dissolved oxygen, $\mathrm{BOD}, \mathrm{pH}$, and $\mathrm{FC}$ on 12-12-2007 for all the sampling stations in the Akkulam-Veli Lake, are used to estimate NSFWQI using Eq. (1), and the equations in Table (1). The values of DO, BOD, pH, FC, and NSFWQI thus obtained are given in Table 4. For the development of regression model, radiance from the respective sampling stations obtained from the analysis of satellite imagery, are used as independent variables

\begin{tabular}{|l|l|l|l|l|l|l|}
\hline $\begin{array}{l}\text { Sampling } \\
\text { station }\end{array}$ & $\begin{array}{l}\text { \% saturation } \\
\text { DO }\end{array}$ & $\begin{array}{l}\text { BOD in } \\
\mathbf{m g} / \mathbf{l}\end{array}$ & $\mathbf{p H}$ & $\begin{array}{l}\text { FC (no. per } \\
\mathbf{1 0 0} \mathbf{m l})\end{array}$ & NSFWQI & $\begin{array}{l}\text { NSFWQI } \\
\text { description }\end{array}$ \\
\hline 2 & 1 & 8.4 & 6.5 & 500 & 30.9 & Bad \\
\hline 5 & 11 & 3 & 6.7 & 200 & 39.4 & Bad \\
\hline 6 & 0 & 9 & 6.6 & 100 & 35.9 & Bad \\
\hline 7 & 47 & 1.4 & 6.9 & 1500 & 53.8 & Medium \\
\hline 8 & 21 & 6.4 & 6.8 & 100 & 45.1 & Bad \\
\hline 9 & 55 & 0.9 & 7 & 500 & 60.1 & Medium \\
\hline 10 & 38 & 1.4 & 6.8 & 1000 & 48.4 & Bad \\
\hline 11 & 56 & 0.3 & 6.7 & 50 & 66.6 & Medium \\
\hline
\end{tabular}

Table 4: NSFWQI estimated from the Field Data on 12-12-2007.

\begin{tabular}{|l|l|l|l|l|}
\hline \multirow{2}{*}{ Station } & \multicolumn{4}{|c|}{ Radiance from the satellite imagery taken on 12-12-2007 } \\
\cline { 2 - 3 } & Green & Red & NIR & MIR \\
\hline 2 & 3.548 & 2.136 & 2.225 & 0.413 \\
\hline 5 & 3.86878 & 2.413 & 2.1972 & 0.338778 \\
\hline 6 & 3.705667 & 2.346889 & 2.12867 & 0.33411 \\
\hline 7 & 3.87933 & 2.44611 & 2.20411 & 0.34922 \\
\hline 8 & 3.9738 & 2.54 & 2.2986 & 0.3834 \\
\hline 9 & 4.100333 & 2.6801667 & 2.461667 & 0.413 \\
\hline 10 & 4.163 & 2.73 & 2.317 & 0.3795 \\
\hline 11 & 4.334875 & 2.862875 & 2.27075 & 0.386 \\
\hline
\end{tabular}

Table 5: Radiance from the Satellite Imagery dated 12-12-2007 (Sheela et al. 2010).
(Table 5) and one of the parameters namely NSFWQI, DO, BOD, $\mathrm{pH}$, and FC is used as the dependent variable.

\section{Regression equations using NSFWQI as dependent variable}

For developing simple linear regression equations as mentioned earlier, SPSS software is used. A correlation matrix is computed using SPSS for obtaining the relationship between the radiance in different bands with NSFWQI. The radiance in the green and red bands is strongly correlated to NSFWQI from the field data with a significant level of 1\% (Table 6). Simple regression equations with independent variables as the radiance in green band and radiance in the red band respectively with NSFWQI are developed. The regression equations derived are as follows:

$$
\begin{aligned}
& \text { NSFWQI }=-119.921+42.42 \mathrm{R}_{\mathrm{g}}(\mathrm{r}=0.881) \\
& \mathrm{NSFWQI}=-67.647+45.715^{*} \mathrm{R}_{\mathrm{r}}(\mathrm{r}=0.875)
\end{aligned}
$$

Where in

NSFWQI -National Sanitation Federation Water Quality Index for the station concerned.

$\mathrm{R}_{\mathrm{g}}$-Radiance in the green band for the station under consideration.

$\mathrm{R}_{\mathrm{r}}$-Radiance in the red band for the station concerned

A correlation matrix is formed for choosing the best relationship between the ratio of radiance in different bands with NSFWQI. It shows that NSFWQI has a strong correlation with the ratio of the radiance in green and red bands $(\mathrm{r}=-0.814)$ with $1 \%$ significance level (Table 6$)$. The equation thus developed using the ratio of radiance in green and red bands, is given as follows:

$$
\text { NSFWQI }=368.766-204.567^{\star} R_{g}(r=-0.814)
$$

$\mathrm{Rr}$

\section{Where in}

NSFWQI -National Sanitation Federation Water Quality Index for the station concerned.

$\mathrm{R}_{\mathrm{g}}$-Ratio of radiance in green and red bands for the station under

$\mathrm{R}_{\mathrm{r}}$ consideration.

A multiple linear regression equation is developed using the radiance in all four bands (green, red, NIR, and SWIR) as independent variables and NSFWQI as dependent variable. SPSS software is used for this purpose. This has resulted in a very low tolerance and high eigen value condition indices due to strong correlation between green and red. Hence multiple regression equations are also formed using different combinations of independent variables. They are respectively the reflectance in red, NIR, and SWIR bands; red and NIR; and in red and SWIR. High tolerance values and low eigen value condition index are obtained for the multiple regression equation formed using red and SWIR. Hence this equation is considered to be more dependable. The equation takes the following form:

NSFWQI $=-78.574+44.873{ }^{\star} R_{r}+34.829^{\star} R_{m}(r=0.879)$

Where in

NSFWQI-National Sanitation Federation Water Quality Index for them station concerned.

$\mathrm{R}_{\mathrm{r}}$-Radiance in the red band for the station concerned

$\mathrm{R}_{\mathrm{m}}$-Radiance in the SWIR band for the station concerned

Both the independent variables have positive correlation on the 
Citation: Sheela AM, Letha J, Joseph S, Ramachandran KK, Justus J (2013) Assessment of Pollution Status of a Coastal Lake System using Satellite Imagery. J Geophys Remote Sensing 2: 110. doi:10.4172/2169-0049.1000110

Page 6 of 11

\begin{tabular}{|c|c|c|c|c|c|c|c|c|c|c|c|}
\hline & Green & Red & NIR & MIR & Green/Red & Red/NIR & Red/MIR & Green/NIR & Green/MIR & NIR/MIR & NSFWQI \\
\hline Green & 1.000 & $.994^{* *}$ & .575 & .192 & $-.927^{* *}$ & $.879^{* *}$ & .661 & $.741^{*}$ & .477 & .109 & $.881^{* *}$ \\
\hline Red & & 1.000 & .581 & .182 & $-.962^{* *}$ & $.884^{* *}$ & .673 & $.729^{*}$ & .481 & .127 & $.875^{\star *}$ \\
\hline NIR & & & 1.000 & $.737^{*}$ & -.550 & .133 & -.087 & -.122 & -.286 & -.328 & .577 \\
\hline MIR & & & & 1.000 & -.086 & -.208 & -.605 & -.381 & $-.770^{*}$ & $-.879^{* *}$ & .245 \\
\hline Green/Red & & & & & 1.000 & $-.857^{* *}$ & $-.711^{*}$ & -.677 & -.519 & -.238 & $-.814^{*}$ \\
\hline Red/NIR & & & & & & 1.000 & $.874^{* *}$ & $.959^{* *}$ & $.755^{\star}$ & .351 & $.737^{*}$ \\
\hline Red/MIR & & & & & & & 1.000 & $.881^{* *}$ & $.969^{* *}$ & $.761^{*}$ & .524 \\
\hline Green/NIR & & & & & & & & 1.000 & $.822^{*}$ & .415 & .600 \\
\hline Green/MIR & & & & & & & & & 1.000 & $.859^{* *}$ & .354 \\
\hline NIR/MIR & & & & & & & & & & 1.000 & .041 \\
\hline NSFWQI & & & & & & & & & & & 1.000 \\
\hline
\end{tabular}

Table 6: Correlation Matrix for the Radiance of Individual Bands and their Ratio from the Satellite Imagery and NSFWQI from Field Data on $12-12-2007$.

\begin{tabular}{|l|l|l|l|l|}
\hline \multirow{2}{*}{ Station } & \multicolumn{4}{|l|}{ Radiance from the satellite imagery taken on } \\
\cline { 2 - 5 } & Green & Red & NIR & MIR \\
\hline 4 & 3.596 & 2.195 & 4.696 & 0.386 \\
\hline 5 & 3.832 & 2.314 & 3.708 & 0.52 \\
\hline 6 & 3.737 & 2.255 & 2.348 & 0.266 \\
\hline 7 & 4.211 & 2.67 & 2.101 & 0.52 \\
\hline 8 & 4.069 & 2.67 & 1.916 & 0.386 \\
\hline 9 & 3.974 & 2.611 & 3.46 & 0.373 \\
\hline 10 & 4.069 & 2.611 & 2.410 & 0.373 \\
\hline 11 & 4.447 & 2.908 & 2.039 & 0.466 \\
\hline
\end{tabular}

Table 7: Radiance from the Satellite Imagery dated 16-2-2009 (Sheela et al. 2010).

\begin{tabular}{|c|c|c|c|c|c|}
\hline \multirow[t]{2}{*}{ Station } & \multirow{2}{*}{$\begin{array}{l}\text { Actual } \\
\text { value of } \\
\text { NSFWQI }\end{array}$} & \multicolumn{4}{|c|}{ Predicted value of NSFWQI } \\
\hline & & $\begin{array}{l}\text { Equation } 2 \\
\text { (green) }\end{array}$ & $\begin{array}{l}\text { Equation } 3 \\
\text { (red) }\end{array}$ & $\begin{array}{l}\text { Equation } 4 \\
\text { (green and red } \\
\text { ratio) }\end{array}$ & $\begin{array}{l}\text { Equation } 5 \\
\text { (red and MIR) }\end{array}$ \\
\hline 4 & 32.1 & 32.6 & 32.7 & 33.6 & 33.4 \\
\hline 5 & 31.5 & 42.7 & 38.1 & 30 & 43.4 \\
\hline 6 & 37.6 & 38.6 & 35.4 & 29.8 & 31.9 \\
\hline 7 & 36 & 58.7 & 54.4 & 46.1 & 59.3 \\
\hline 8 & 48.05 & 52.7 & 54.4 & 57 & 54.7 \\
\hline 9 & 60.2 & 48.7 & 51.7 & 57.4 & 51.6 \\
\hline 10 & 58.9 & 52.7 & 51.7 & 50 & 51.6 \\
\hline 11 & 66.4 & 68.8 & 65.3 & 56 & 68.1 \\
\hline \multicolumn{2}{|c|}{$\begin{array}{l}\text { Correlation coefficient } \\
\text { of actual value with } \\
\text { predicted value }\end{array}$} & 0.68 & 0.78 & 0.83 & 0.67 \\
\hline
\end{tabular}

Table 8: Actual and Predicted Values of NSFWQI on 16-2-2009.

dependent variable. It is also found that the effect of radiance in the red band is more prominent on NSFWQI since the coefficient of radiance in the red band is 1.5 times that of radiance in the SWIR band.

\section{Validation of regression equations}

The regression equations thus developed (Equations (2) to (5)) are to be validated for their future application. The satellite imagery of 162-2009 and NSFWQI estimated from the measured values of DO, BOD, $\mathrm{pH}$, and FC on 16-2-2009 are used for this purpose.

Satellite imagery which is converted into the corresponding imagery of radiance values for 16-2-2009 is input into the software (Table 7). The different sets of regression equations thus developed to predict NSFWQI are also input one by one into the model. The output obtained is NSFWQI values predicted by the equations for 16-2-2009. These are compared with NSFWQI values estimated using equation (1)

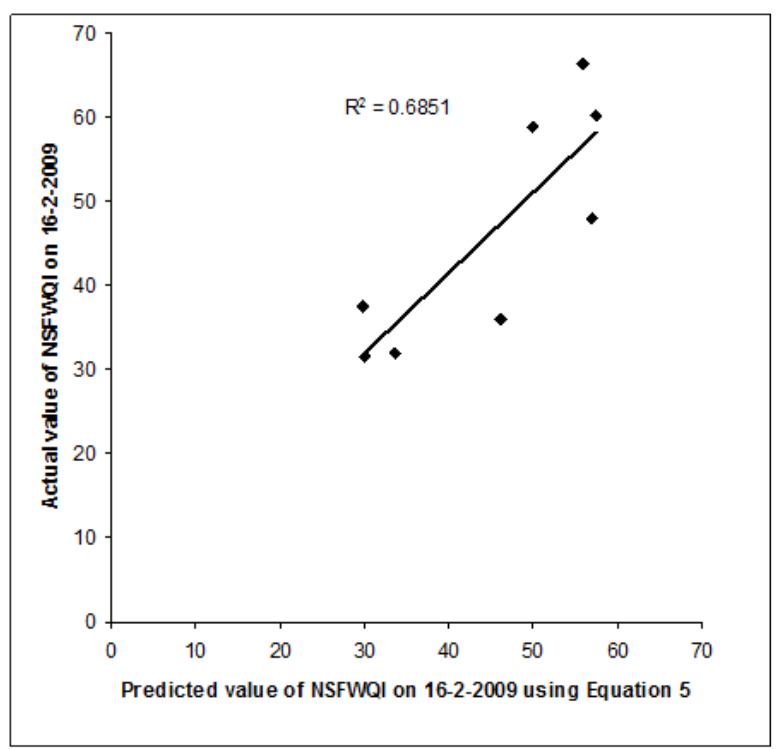

Figure 5: Scatter Plot Showing Relationship between the Predicted Values of NSFWQI on 16-2-2009 using Equation (4) and Actual Values.

from the measured values of $\mathrm{DO}, \mathrm{BOD}, \mathrm{pH}$, and $\mathrm{FC}$ for 16-2-2009. The coefficient of correlation thus obtained for the different equations, is given in Table 8.

The predicted value of NSFWQI using Eq. (4) has strong correlation $(\mathrm{r}=0.83)$ with those of the actual values of this parameter on 16-22009 (Figure 5). From the correlation coefficient values obtained as evident from Table 8, it is seen that the simple regression equation (Eq. (4)) formed by the ratio of radiance in the green and the red bands, which yields a correlation coefficient of 0.83 , is the best suited for the prediction of NSFWQI. This is similar to the findings of Gitelson et al. [25] wherein it is stated that the reflectance in the red region is very important for the remote sensing of inland and coastal waters.

\section{Regression equations using DO, BOD, $\mathrm{pH}$, and $\mathrm{FC}$ as} dependent variables

For the development and calibration of regression equations using DO, BOD, pH, and FC as dependent variables, all analyses, as done for NSFWQI in section 4.3 and 4.3.1, are carried out. The values of DO, $\mathrm{BOD}, \mathrm{pH}$, and $\mathrm{FC}$ are given in Table 4 . The best equations in each case for predicting $\mathrm{DO}, \mathrm{BOD}, \mathrm{pH}$, and $\mathrm{FC}$ are given in Table 9.

The best equation for predicting DO (Eq. (6) in Table 9) is the 
Citation: Sheela AM, Letha J, Joseph S, Ramachandran KK, Justus J (2013) Assessment of Pollution Status of a Coastal Lake System using Satellite Imagery. J Geophys Remote Sensing 2: 110. doi:10.4172/2169-0049.1000110

Page 7 of 11

\begin{tabular}{|c|c|c|}
\hline Parameter & Best Suited Equation & Definition of Variables \\
\hline DO & $\begin{array}{r}D O=60.209-36.518^{*} R_{g} \\
R_{r}\end{array}$ & $\begin{array}{l}\text { DO-Concentration of dissolved oxygen in } \mathrm{mg} / \mathrm{l} \text { in the station concerned. } \\
\mathrm{R}_{\mathrm{g}} \text {-Radiance in the green band for the station concerned } \\
\mathrm{R}_{\mathrm{r}} \text {-Radiance in the red band for the station concerned }\end{array}$ \\
\hline BOD & $B O D=32.465-11.923^{*} R r+3.799^{*} R_{m}$ & $\begin{array}{l}\text { BOD-Concentration of BOD in } \mathrm{mg} / \mathrm{l} \text { in the station concerned. } \\
\mathrm{R}_{\mathrm{r}} \text {-Radiance in red band for the station concerned } \\
\mathrm{R}_{\mathrm{m}} \text {-Radiance in MIR band for the station concerned }\end{array}$ \\
\hline $\mathrm{pH}$ & $\begin{array}{r}\mathrm{pH}=9.901-2.007^{*} \mathrm{R}_{\mathrm{g}} \\
\mathrm{R}_{\mathrm{r}}\end{array}$ & $\begin{array}{l}\mathrm{pH}-\mathrm{pH} \text { value in the station concerned. } \\
\mathrm{R}_{\mathrm{g}} \text {-Radiance in green band for the station concerned } \\
\mathrm{R}_{\mathrm{r}} \text {-Radiance in red band for the station concerned }\end{array}$ \\
\hline FC & $\begin{array}{r}F C=-1921.81+249.411 R_{g} \\
R_{m}\end{array}$ & $\begin{array}{l}\text { FC-Fecal coliform in no./100 } \mathrm{ml} \text { in the station concerned. } \\
\mathrm{R}_{\mathrm{g}} \text {-Radiance in green band for the station concerned } \\
\mathrm{R}_{\mathrm{m}} \text {-Radiance in MIR band for the station concerned }\end{array}$ \\
\hline
\end{tabular}

Table 9: Best Equations for Predicting DO, BOD, pH, and FC.

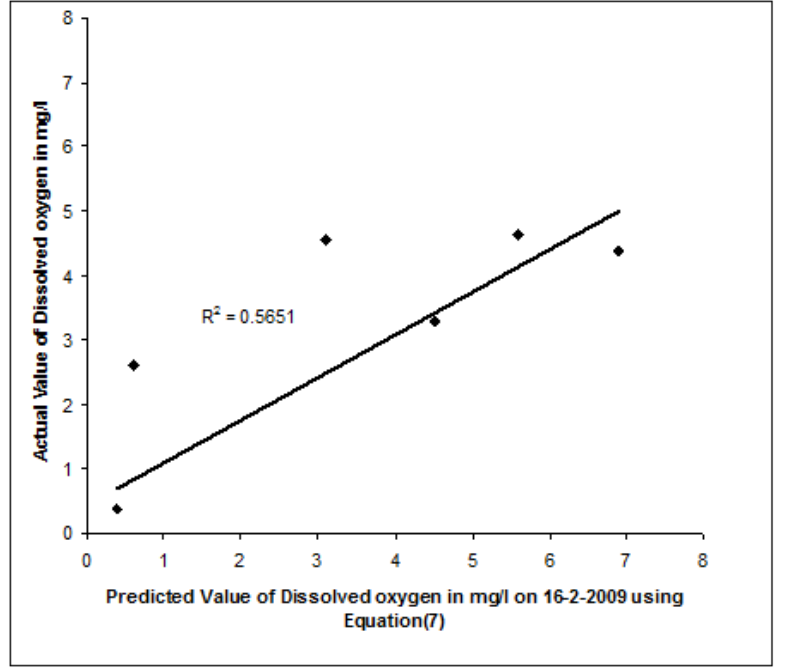

Figure 6: Scatter Plot Showing Relationship between the Predicted Values of Dissolved Oxygen using Equation (6) and Actual Values on 16-2-2009.

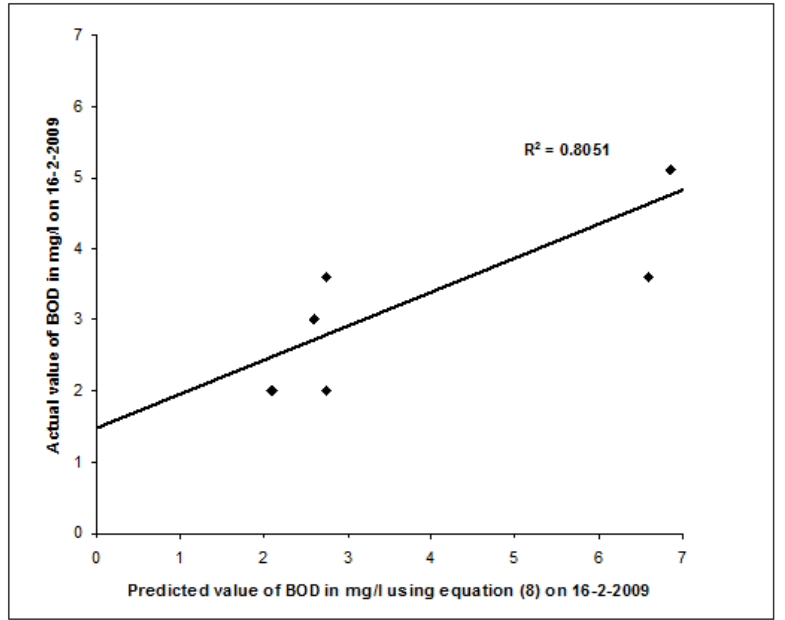

Figure 7: Scatter Plot Showing Relationship between the Predicted Values of BOD using Equation (7) and Actual Values.

simple regression equation formed by the ratio of radiance in green and red bands. The high correlation of DO with the reflectance in the red and NIR bands has already been established by Houma et al. (2004) [16]. The predicted value of DO has good correlation $(\mathrm{r}=0.75)$ with

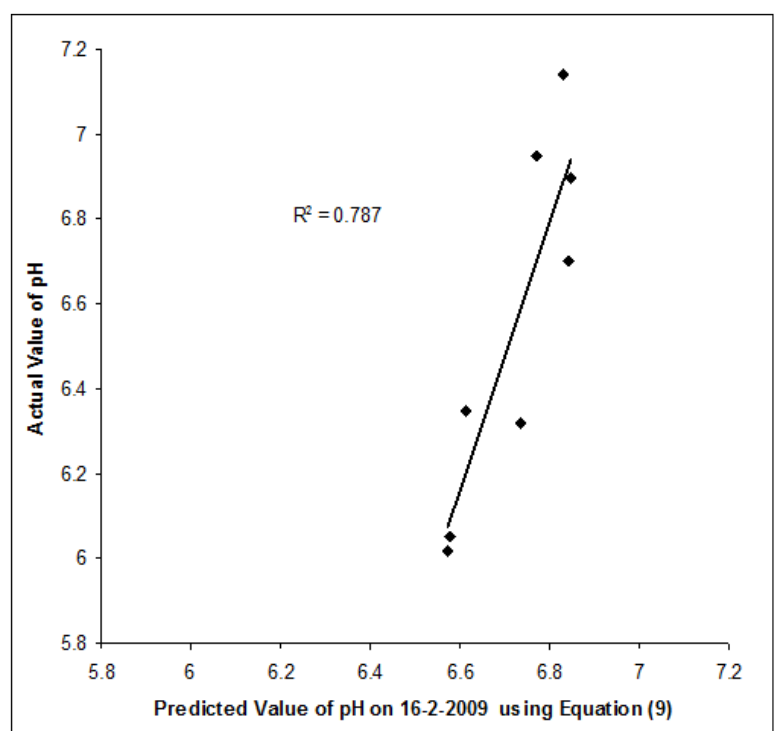

Figure 8: Scatter Plot Showing Relationship between the Predicted Values of $\mathrm{pH}$ using Equation (8) and Actual Value on 16-2-2009.

those of the actual values of this parameter on 16-2-2009 (Figure 6).

The best equation for predicting BOD (Eq.(7) in Table 9) is the multiple regression equation formed by the radiance in the red and SWIR bands. This is similar to the findings of Gitelson et al. (1993) [25] that the reflectance in the red region is very important for the remote sensing of inland and coastal waters. The high correlation of BOD with the reflectance in the red and NIR bands was established by Houma et al. [16]. The predicted values of BOD has strong correlation $(r=0.9)$ with those of the actual values of this parameter (Figure 7).

The best equation for predicting pH (Eq. (8) in Table 9) is the regression equation with the ratio of green and red bands. The predicted values of $\mathrm{pH}$ using this equation has good correlation $(\mathrm{r}=0.89)$ with those of the actual values of this parameter (Figure 8). As the Veli Lake is situated near to the sea, sea water is predominant whereas in the Akkulam Lake, fresh water is predominant. This situation causes the change in refractive index in water and this is responsible for the determination of $\mathrm{pH}$.

The best equation for predicting FC (Eq. (9) in Table 9) is the multiple regression equation formed by the ratio of radiance in the green and SWIR bands. The predicted values of FC using this equation has low correlation $(r=0.51)$ with those of the actual values of this parameter (Figure 9). 


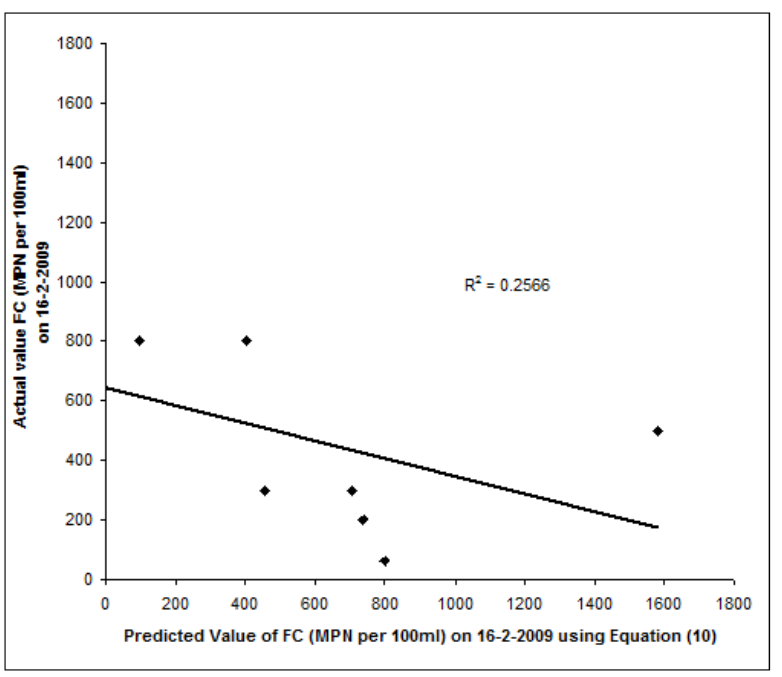

Figure 9: Scatter Plot Showing Relationship between the Predicted Value of FC using Equation (9) and Actual Value.

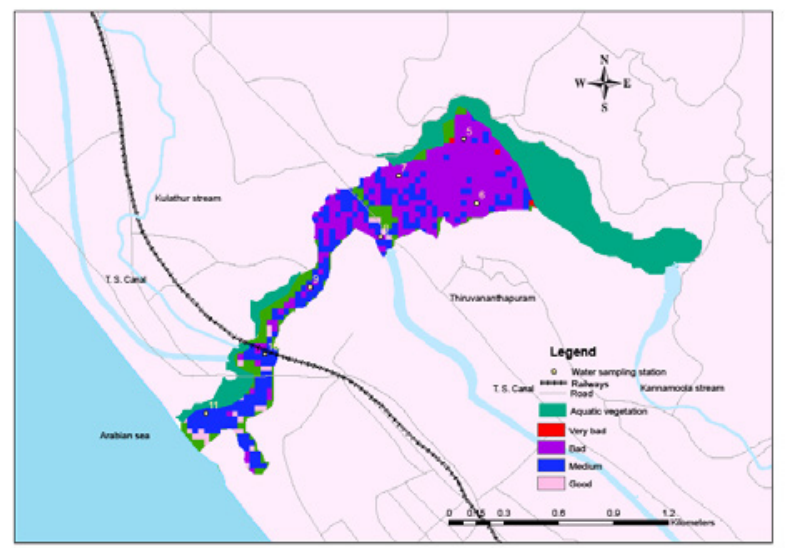

Figure 10: Predicted NSFWQI in the Akkulam-Veli Lake using Equation (4) from the IRS P6-LISSIII imagery on 12-12-2007.

The reflectance for bands in the NIR and SWIR is null for clear water only. Here the study area is highly polluted as per Sheela et al. 2011b. In polluted water, there is reflectance in NIR and SWIR band. In the multiple regression analysis, the radiance values in all bands have been used. But the best multiple regression equation for BOD is obtained by using radiance values in red and SWIR bands and for fecal coliform, the best multiple regression equation is obtained by using ratio of radiance values in green and SWIR bands.

\section{Preparation of maps for NSFWQI, DO, BOD, pH, and FC}

The spatial modeler in ERDAS-Imagine 9.1 software is used for mapping the spatial variation of different water quality parameters. The water quality parameters now under consideration are the NSFWQI, $\mathrm{DO}, \mathrm{BOD}, \mathrm{pH}$, and FC. To map the variation of these parameters throughout the Lake system on 12-12-2007, the satellite imagery of this date showing the radiance is input into this software. Eq. (4), (6) to (9) which have been proved to be the best predicted model in each of the situation under consideration is also input into the software. The software is then run to get the output which is the spatial variation of NSFWQI, DO, BOD, $\mathrm{pH}$, and FC respectively of the entire Lake on 1212-2007 (Figure 10, 12, 14, 16, and 18). The same process is repeated for satellite imagery showing radiance on 16-2-2009 wherein we get the map of NSFWQI, DO, BOD, pH, and FC of the entire Lake on 16-22009 as output (Figure 11, 13, 15, 17, and 19).

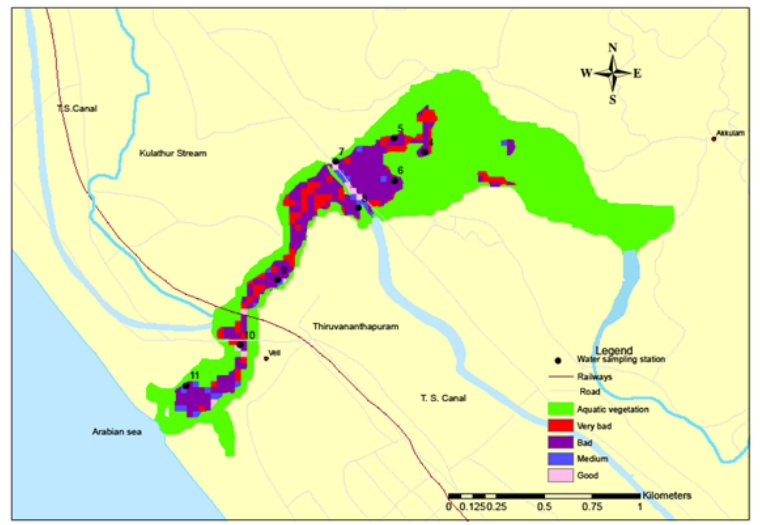

Figure 11: Predicted NSFWQI in the Akkulam-Veli Lake using Equation (4) from the IRS P6-LISSIII imagery on 16-2-2009.

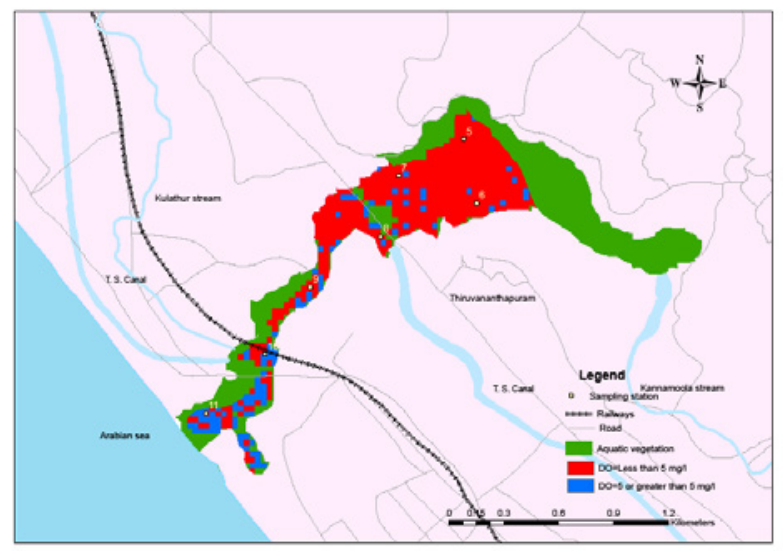

Figure 12: Predicted Dissolved Oxygen in the Akkulam-Veli Lake using Equation (6) from the IRS P6-LISSIII imagery on 12-12-2007.

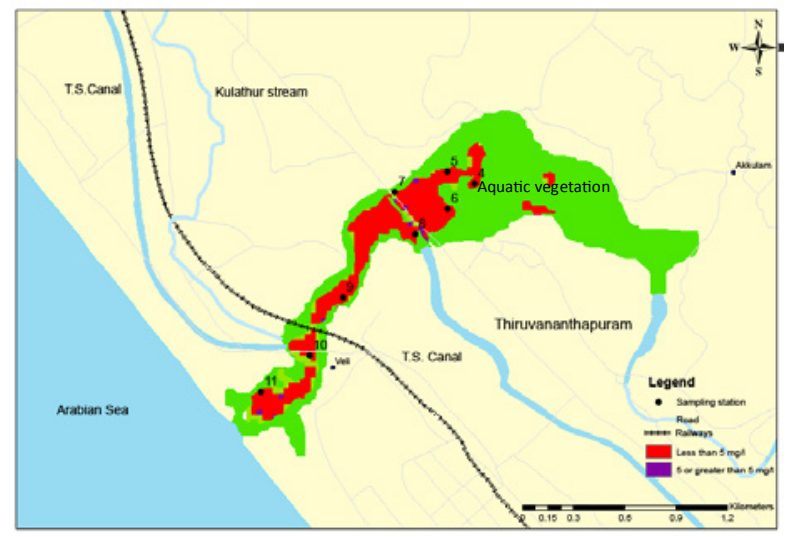

Figure 13: Predicted Value of Dissolved Oxygen in the Akkulam-Veli Lake using Equation (6) from the IRS P6-LISSIII imagery on 16-2-2009. 


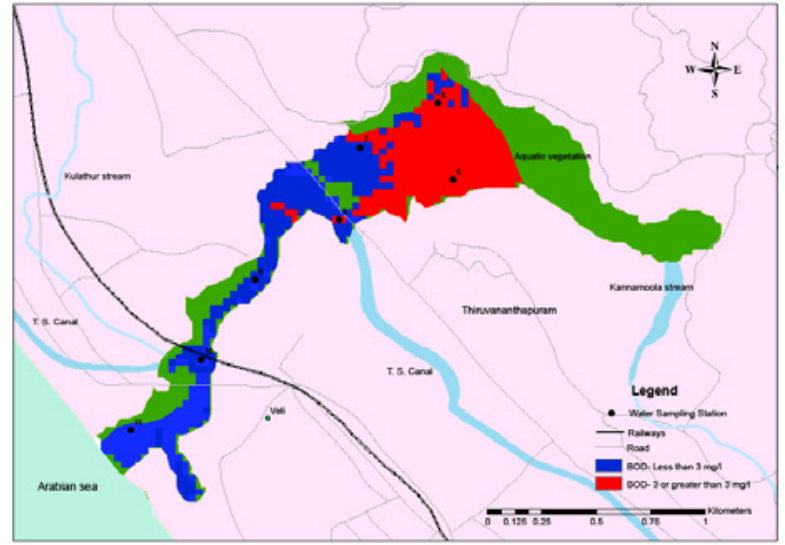

Figure 14: Predicted Value of BOD in the Akkulam-Veli Lake using Equation (7) from the IRS P6-LISSIII Imagery on 12-12-2007.

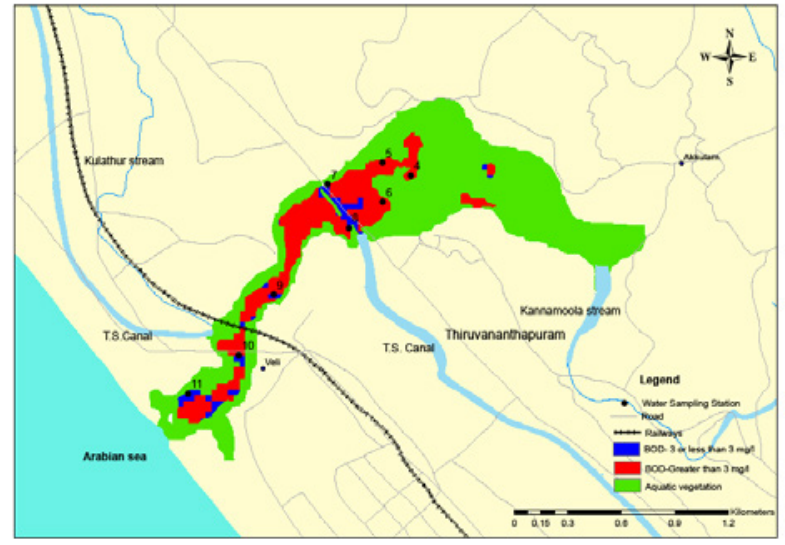

Figure 15: Predicted Value of BOD in the Akkulam-Veli Lake using Equation (7) from the IRS P6-LISSIII Imagery on 16-2-2009.

\section{Spatial variation of NSWQI, DO, BOD, $\mathrm{pH}$, and FC}

The map of 12-12-2007 (Figure 10) shows that the water quality of the entire Akkulam Lake and the upstream portion of the Veli Lake is 'bad' and fall under 'B' category. The water quality of the downstream stretch of the Veli Lake is 'medium' and it belongs to 'C' category. The map of 16-2-2009 (Figure 11) shows that the water quality of the entire stretch of the Akkulam and the Veli Lake is 'very bad' ('A' class) as well as 'bad' ('B' category). The Akkulam-Veli Lake is more polluted on 162-2009 than that on 12-12-2007. The coverage of aquatic vegetation is more on 16-2-2009. The water quality is more polluted as well as the coverage of aquatic vegetation is more near the confluence of Kannamoola stream with the Akkulam Lake. The waste water including sewage entering into this part of this Lake is the main reason for the degradation of water quality.

The Ministry of Environment and Forests (MoEF), Government of India specified the primary water-quality criteria for organized recreational activities for outdoor bathing. The minimum concentration of dissolved oxygen prescribed is $5 \mathrm{mg} / \mathrm{l}$. The map of 12-12-2007 (Figure 12) shows that except in the downstream portion of the Veli Lake, the entire Lake, has dissolved oxygen content less than the limit prescribed. Thus a major portion of the Lake is not conforming to the standards with respect to DO. The map of 16-2-2009 (Figure 13) shows that the entire area of the Akkulam-Veli Lake has the dissolved oxygen content less than the limit of $5 \mathrm{mg} / \mathrm{l}$. Water quality in the entire Lake does not conform to the standards.

As per the limit prescribed by the MoEF, the maximum limit prescribed for BOD value is $3 \mathrm{mg} / \mathrm{l}$. The map of 12-12-2007 (Figure 14) shows that a major portion of the Akkulam Lake has BOD more than $3 \mathrm{mg} / \mathrm{l}$ and the water quality is not conforming to the standards with respect to BOD. The Veli Lake has a BOD value less than $3 \mathrm{mg} / \mathrm{l}$ and the water quality is conforming to the standards. During 16-2-2009, the entire Lake has BOD greater than $3 \mathrm{mg} / \mathrm{l}$ and hence the water quality does not conform to the standards (Figure 15).

The limit for $\mathrm{pH}$ prescribed by the is between 6.5 and 8.5 . The map of 12-12-2007 (Figure 16) shows that the entire area of the AkkulamVeli Lake has $\mathrm{pH}$ more than the lower limit of 6.5 and the water quality conforms to the standards with respect to $\mathrm{pH}$. During 16-2-2009, the $\mathrm{pH}$ does not conform to the standards especially in the upstream portion of the Veli Lake (Figure 17).

The maximum limit for fecal coliforms prescribed is 500 MPN/100ml. The map of 12-12-2007 (Figure 18) shows that almost the entire area of the Akkulam-Veli Lake has fecal coliform count greater than the limit of $500 \mathrm{MPN} / 100 \mathrm{ml}$ and the water quality is not conforming to the standards with respect to FC. During 16-2-2009, the

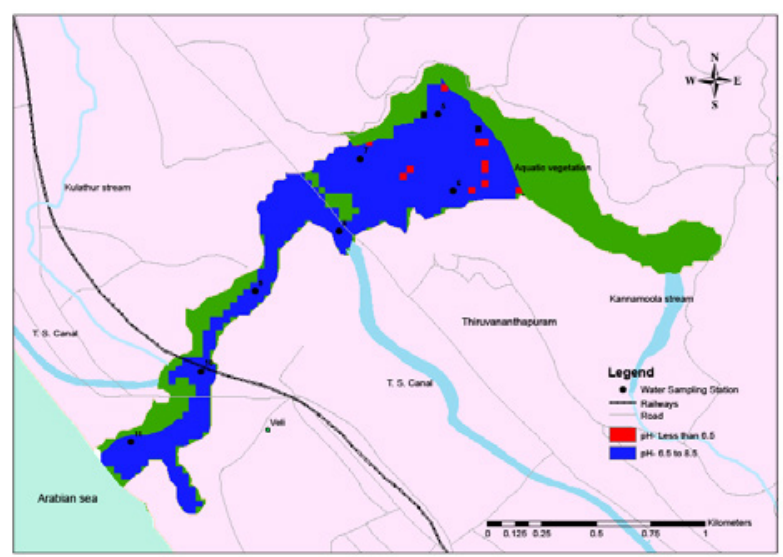

Figure 16: Predicted Value of $\mathrm{pH}$ in the Akkulam-Veli Lake using Equation (8) from the IRS P6-LISSIII Imagery on 12-12-2007.

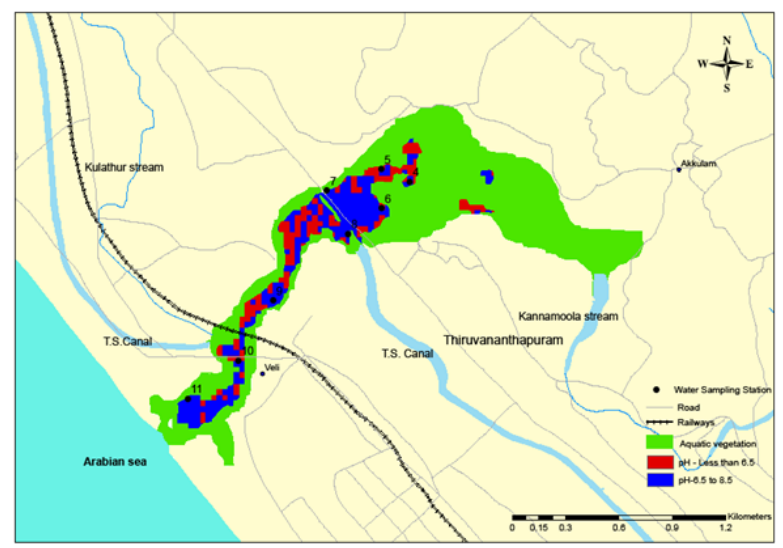

Figure 17: Predicted Value of $\mathrm{pH}$ in the Akkulam-Veli Lake using Equation (8) from the IRS P6-LISSIII Imagery on 16-2-2009. 


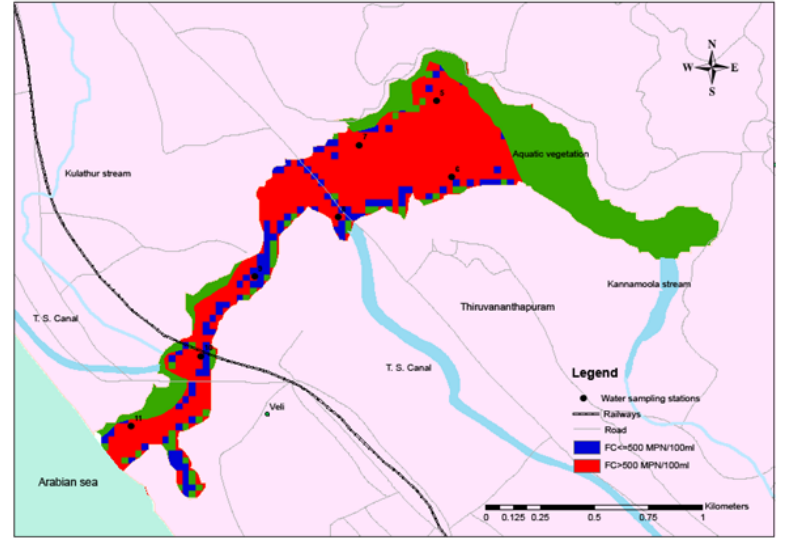

Figure 18: Predicted Value of Fecal Coliforms in the Akkulam-Veli Lake using Equation (9) from the IRS P6-LISSIII Imagery on 12-12-2007.

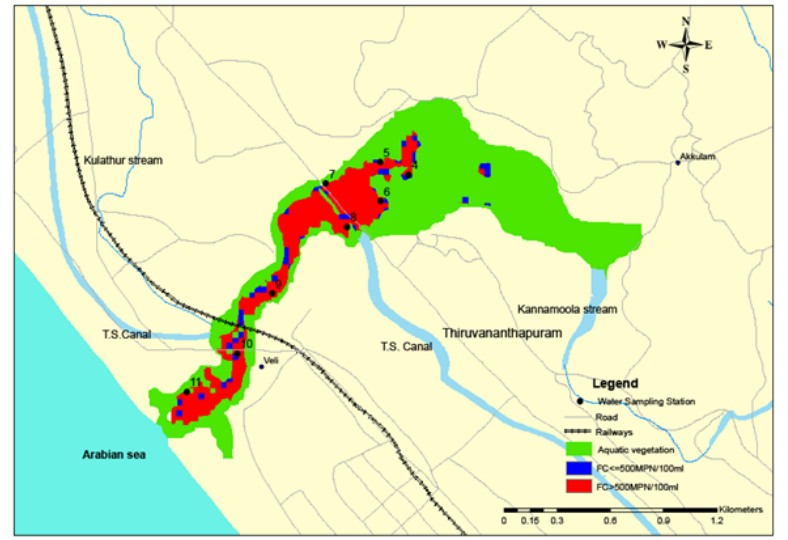

Figure 19: Predicted Value of Fecal Coliforms in the Akkulam Veli Lake using Equation (9) from the IRS P6-LISS III Satellite Imagery on 16-2-2009.

entire Lake has fecal coliform count greater than $500 \mathrm{MPN} / 100 \mathrm{ml}$ and the water quality is not conforming to the standards (Figure 19).

The reflectance for bands in the NIR and SWIR is null for clear water only. Here the study area is highly polluted as per Sheela et al. 2011b. In polluted water, there is reflectance in NIR and SWIR band. In the multiple regression analysis, the radiance values in all bands have been used. But the best multiple regression equation for BOD is obtained by using radiance values in red and SWIR bands and for fecal coliform, the best multiple regression equation is obtained by using ratio of radiance values in green and SWIR bands. A small amount of impurities can cause significant changes in the refractive index of a substance. Substance containing more polarizer groups (aromatic rings) will normally has higher refractive index than substance containing less polarizer groups. (http://www2.ups.edu/faculty/hanson/labtechniques/ refractometry/interpret.htm). The pollutants change the refractive index in water and which in turn changes the reflectance of NIR and SWIR in water.

\section{Summary and Conclusions}

The study has been conducted to quickly assess the water quality of a Lake system (Akkulam-Veli Lake, Kerala, India) directly from IRS P6LISSIII imagery using National Sanitation Federation Water Quality Index. The extent of pollution was also ascertained using oxygen (DO), biochemical oxygen demand (BOD), $\mathrm{pH}$, and fecal coliform from the satellite imagery.

Regression equations for the prediction of NSFWQI, $\mathrm{pH}, \mathrm{DO}, \mathrm{BOD}$ and FC from radiance values from green, red, NIR and SWIR bands of satellite imagery were developed. The study reveals that the simple regression equation formed by the ratio of radiance in the green and the red bands, which yields a strong correlation coefficient of 0.83 and a standard error of 8.45 with those of the actual values of field observations, is the best suited for the prediction of NSFWQI.

For the prediction of DO, the best equation is the simple regression equation formed by the ratio of radiance in green and red bands with a strong correlation of 0.75 and a standard error of 1.75. For BOD, multiple regression equation formed by the radiance in the red and SWIR bands with a strong correlation coefficient of 0.9 and a standard error of 0.73 . The best equation for predicting $\mathrm{pH}$ is the regression equation with the ratio of green and red bands with a strong correlation coefficient of 0.89 and a standard error of 0.21 . But for fecal coliform, multiple regression equation is the best equation formed by the ratio of radiance in the green and SWIR bands with a low correlation coefficient of 0.51 and high standard error of 278.6. The performance of the model can be improved by using a large set of data.

The predictive map of NSFWQI obtained from the satellite imagery shows that during 12-12-2007, the entire Akkulam Lake and the upstream portion of the Veli Lake falls under 'bad' category whereas the during 16-2-2009, the entire Lake falls under 'very bad' category. The water quality was not conforming to the standards with respect to DO and BOD in the major portion of the Lake during 12-12-2007 and in the entire Lake during 16-2-2009. The water quality is not conforming to the standards with respect to fecal coliforms in the entire Lake on both days.

The degradation of water quality is due to the disposal of a large quantity of wastewater, including sewage, generated in the Thiruvananthapuram city, into the upstream portion of the Akkulam Lake. Almost all the tropical Lakes in the World are facing similar situation due to pollution caused by anthropogenic activities. Hence IRS P6-LISSIII imagery can give a quick assessment of the badly affected area and accordingly, control measures can be adopted on war footing. The spatial temporal variation of $\mathrm{DO}, \mathrm{BOD}, \mathrm{pH}$, and $\mathrm{FC}$ can be compared with the prescribed limits for these important parameters. The technique allows for the necessary continuous monitoring of impacted areas and provides an overall analysis of their degree of pollution. The accuracy of the models can be increased by enhancing the number of field observations.

\section{Acknowledgements}

The first author is grateful to Kerala State Pollution Control Board, College of Engineering, Thiruvananthapuram, and Department of Environmental Sciences Department of Statistics, and Department of Geology of the University of Kerala for providing all help in this study. I am thankful to Dr. Manoj Chacko, Department of Statistics, University of Kerala and Shri. Sanal Kumar S.P. of the Department of Future Studies, University of Kerala for his valuable suggestions. The first author is thankful to Prof. M. O. Thomas and Shri. A. Moses for language correction.

\section{References}

1. Lumb A, Sharma TC, Bibeault JF (2011) A review of genesis and evolution of water quality index (WQI) and some future directions. Water qual Expo Health 3: 11-24.

2. IOCCG (2000) Remote sensing of ocean colour in coastal, and other opticallycomplex, waters. In Reports of the international Ocean-Colour Coordinating Group, Salthyendranath S (Ed.), pp. 1-140 (Dartmouth, NS: IOCCG).

3. Dekker AG, Peters SWM (1993) The use of Thematic Mapper for the analysis 
Citation: Sheela AM, Letha J, Joseph S, Ramachandran KK, Justus J (2013) Assessment of Pollution Status of a Coastal Lake System using Satellite Imagery. J Geophys Remote Sensing 2: 110. doi:10.4172/2169-0049.1000110

of eutrophic lakes: a case study in the Netherlands. International Journal of Remote Sensing 14: 799-821.

4. Schneider K., Mauser W (1996) Processing and accuracy of Landsat thematic mapper for lake surface temperature measurement. International Journal of Remote Sensing 11: 2027-2041.

5. Zilioli E, Brivio PA (1997) The satellite derived optical information for the comparative assessment of lacustrine water quality. The Science of Total Environment J 196: 229-245.

6. Fraser RS (1998) Multispectral remote sensing of turbidity among Nebraska Sand Hills lakes. Int J Remote Sensing 19: 3011-3016.

7. Giardino C, Pepe M, Brivio PA, Ghezzi P, Zilioli E (2001) Detecting chlorophyll, Secchi disk depth and surface temperature in a sub-alpine lake using Landsat imagery. Sci Total Environ 268: 19-29.

8. Brezonik PL, Kloiber SM, Olmanson L, Bauer M (2002) Satellite and GIS Tools to Assess Lake Quality. University Minnesota, Water Resources Center, Technical report 145

9. Olmanson LG (1997) Satellite remote sensing of the trophic state conditions of the lakes in the Twin Cities Metropolitian Area. MS Paper. Water Resources Science, University of Minnesota, MN

10. OImanson LG, Bauer ME, Brezonik (2008) Development and analysis of a 20-year Landsat water clarity census of Minnesota's 10,000 lakes. Remote Sensing of Environment, special issue on Monitoring Freshwater and Estuarine Systems.

11. Lillesand TM, Johnson WL, Deuell RL, Lindstrom OM, Meisner DE (1983) Use of Landstat Data to predict the Trophic State of Minnesota lakes. Photogammetric Engineering and Remote Sensing 49: 219-229.

12. Lathrop RG, Lillesand TM (1989) Monitoring Water quality and River Plume Transport in Green Bay, Lake Michigan with SPOT-I imagery. Photogrammetric Engineering and Remote Sensing 55: 349-354

13. Ritchie JC, Cooper CM (1991) An algorithm of Estimation Surface Suspended Sediment concentrations with landsat MSS Digital Data. Water Resources bulletin 27: 373-379.

14. Vincent RK, McKay RM, Al-Rshadiat MMD, Czajkowski K, Bridgeman T, et al (2005) Mapping the bacterial content of surface waters with Landsat TM data: Importance for monitoring global surface sources of potable water.
15. Wang Y, Xia H, Fu J, Sheng G (2004) Water quality change in reservoirs of Shenzhen, China: detection using LANDSAT/TM data. Sci Total Environ 328: 195-206.

16. Houma F, Belkessa R, Khonider A, Bachari N, Derriche Z (2004) The characterization of aquatic pollution using correlative analysis of physico chemical parameters and data from the IRS-1C data: Application to Oran city, Algeria. Revue des sciences de leau Rev Sci Eau 17: 429-446.

17. Mabwoga SO, Chawla A, Thukral AK (2010) Assessment of water quality parameters of the Harike wetland in India, a Ramsar site, using IRS LISS IV satellite data. Environ Monit Assess 170: 117-128.

18. Samantray P, Basanta KM, Chitta RP, Swoyam PR (2009) Assessment of water quality index in Mahanadi and Atharabanki rivers and Taldanda canal in Paradip area, India. Journal of Human Ecology 26: 153-161.

19. Sheela AM, Letha J, Joseph S (2009) Assessment of the environmental status of the Akkulam-Veli lake, Southern Kerala with special emphasis on organised recreational activities. Proceedings of the National Seminar on Emerging Trends in Environment and Development with a focal theme on climate change and water resources, Department of Environmental Sciences, University of Kerala on 8-9th October, 2009.

20. Sheela AM, Letha J, Joseph S, Ramachandran KK, Sanalkumar SP (2011) Trophic state index of a lake system using IRS (P6-LISS III) satellite imagery. Environ Monit Assess 177: 575-592.

21. Sheela AM, Letha J, Joseph S, Ramachandran KK, Sanalkumar SP (2010) Trophic state index of a lake system using IRS (P6-LISS III) satellite imagery. Environ Monit Assess 177: 575-592.

22. APHA (2005) Standard methods for the examination of water and waste water. $26^{\text {th }}$ Edition, American Public Health Association, Washington DC, pp. 55

23. Ott WR (1978) Environmental indices: Theory and practice. Ann Arbor Science Washington DC, pp. 371

24. CPCB (1986) Manual for statistical analysis and interpretation of water quality data. Published technical report of Central Pollution Control Board, Delhi.

25. Gitelson A, Garbuzov G, Szilagyi F, Mittenzwey KH, Karnieli K, et al. (1993) Quantitative remote sensing methods for real time monitoring of inland water quality. International Journal of Remote Sensing 14: 1269-1295. 